\title{
Absolute counts of peripheral blood leukocyte subpopulations in intraabdominal sepsis and pneumonia-derived sepsis: a pilot study
}

\author{
Grazyna Anna Hoser', Tomasz Skirecki', 3, Małgorzata Złotorowicz ${ }^{3}$, \\ Urszula Zielińska-Borkowska ${ }^{3}$, Jerzy Kawiak ${ }^{2}$ \\ ${ }^{1}$ Department of Clinical Cytology, Medical Center of Postgraduate Education, Warsaw, Poland \\ ${ }^{2}$ Laboratory of Flow Cytometry, Medical Center of Postgraduate Education, Warsaw, Poland \\ ${ }^{3}$ Department of Anesthesiology and Intensive Care, Medical Center of Postgraduate Education, \\ Warsaw, Poland
}

\begin{abstract}
The leading pathophysiological changes during sepsis include systemic abnormalities in the immune response. Due to the general character of these disturbances, sepsis is usually studied as a homogenous clinical condition. We aimed to compare the immune response in intraabdominal sepsis (IAS) and pneumonia-derived sepsis (PDS). The following cell populations were examined: white blood cell count (WBC), monocytes, lymphocytes: $\mathrm{CD}^{+}, \mathrm{CD}^{+}$and $\mathrm{CD} 8^{+} \mathrm{T}$ cells, $\mathrm{B}$ cells, and NK cells. In both studied groups (i.e. IAS and PDS), the WBC was elevated. However, it was significantly higher in the IAS group than in the PDS group. The difference was due to a lower granulocyte count, as well as a lower monocyte count in PDS. We found no significant correlation between the total lymphocyte number and $\mathrm{CD}^{+}{ }^{+} \mathrm{CD} 8{ }^{+} \mathrm{T}$ cells in either form of sepsis. Similarly, we observed no correlation between the total lymphocyte number and the NK cells subset in IAS. However, the numbers of $\mathrm{CD}^{+}{ }^{+} \mathrm{CD}^{+}$and NK cells correlated similarly in both types of sepsis. Both studied types of sepsis induced profound lymphocytopenia, with marked loss of $\mathrm{CD}^{+} \mathrm{T}$ cells and the NK cells. However, the similar relation between them, which was independent of the infection type, suggests that the $\mathrm{NK}$ and $\mathrm{CD} 3^{+} \mathrm{CD} 8^{+}$cells have shared mechanisms of regulation. The primary site of infection has an impact on the global immune reaction. These alternations include especially myeloid cells: granulocytes and monocytes which disappear from peripheral blood during PDS, but increase in IAS. (Folia Histochemica et Cytobiologica 2012, Vol. 50, No. 3, 420-426)
\end{abstract}

Key words: intraabdominal sepsis, pneumonia-derived sepsis, flow cytometry, natural killer cells, cytotoxic T lymphocytes

\section{Introduction}

Sepsis remains the main cause of death in intensive care units (ICU) in the United States and Europe. Although mortality rates in sepsis have been slightly reduced, the occurrence of sepsis is still growing [1]. The increase in the number of septic patients is related to more invasive medical procedures, the development of peritoneal nutrition techniques, and the

Correspondence address: G.A. Hoser,

Department of Clinical Cytology,

Medical Center of Postgraduate Education

Marymoncka Str. 99/103, 01-813 Warsaw, Poland;

e-mail: graho@cmkp.edu.pl ageing of populations. Due to the introduction of sepsis bundles and the improvement of standard therapies, mortality in sepsis is decreasing [2]. However, the outcome of generally applied therapies is not satisfactory. As immune system dysfunction is thought to be crucial in the pathophysiology of sepsis, more studies in this field are necessary.

It is known that the first stage of the septic reaction is characterized by hyperactivity of the immune system. Leukocytosis, a massive production of pro(TNF, IL1, IL6, etc) and anti- (IL10, TGF $\beta$, IL1Ra, etc) inflammatory cytokines, is typical [3]. The release of inflammatory cytokines is responsible for many 
septic symptoms, like hypotension and hypoperfusion. This state is followed by the reaction called the compensatory antiinflammatory system (CARS), which is characterized by an increased concentration of antiinflammatory mediators, in particular IL-10. CARS also typically involves a decrease in the number of lymphocytes, especially CD4(+) cells, B cells, and monocytes [3]. The immunosuppressive effect of sepsis also includes profound dysfunctions of phagocytic activity, antigen presentation, lymphocyte proliferation and production of cytokines. Altogether, these events may result in secondary infections and therapeutic failure.

Sepsis is a generalized response to an infection which can originate in different sites, e.g. lung, abdomen, urinary tract, or the site of the central venous catheter placement. Most research papers do not distinguish sepsis according to the site of the primary infection. Some studies have compared the immune response to Gram positive and Gram negative pathogens, which may also be related to the infection site [4]. In this study, we have compared selected components of the cellular immune response in sepsis of pneumonia and peritonitis origin during the later phase of the sepsis (4-6 days). Both types of infection are common clinical problems and quite often become a source of sepsis. We chose lungs and the peritoneal cavity as the primary of infection sites due to their unusual and specific immune regimens. Although both are parts of the immune system, they are also site-specific and differ from each other significantly $[5,6]$. Moreover, there was some suggestion from the study into the application of an activated protein $\mathrm{C}$ in sepsis (PROWESS) that patients with sepsis derived from pneumonia may have greater benefit from this biological therapy [7]. We focused on patients in septic shock who were in a critical state. To the best of our knowledge, there has previously only been one paper focusing on the early cellular response in sepsis derived from different sites [8].

\section{Material and methods}

Patients. The study was approved by the Postgraduate Medical School Center Ethics Committee. Sampling and laboratory analyses were performed in the Intensive Care Unit (ICU) of the Postgraduate Medical School Center, Warsaw, Poland, and written informed consent was provided by patients, or by two anesthesiology and intensive care specialists if the patient was unconscious. Between four and six days after the diagnosis of sepsis, circulating leukocytes of 22 patients with septic shock were analyzed. Also, 21 healthy subjects were analyzed as controls. We used flow cytometry to evaluate and monitor the blood lymphocyte subpopulations in a cohort of therapy-resistant patients who formed the source of data for this study. Patients were chosen based on the diagnosis of sepsis originating from pneumonia or peritonitis. The sepsis diagnostic criteria were based on ACCP/SCMM Consensus Conference definitions [9]. Briefly, sepsis was diagnosed in patients with a confirmed or suspected infection and at least two of the following: hyperthermia $\left(>38^{\circ} \mathrm{C}\right)$ or hypothermia $\left(<36^{\circ} \mathrm{C}\right)$, heart rate $>90 / \mathrm{min}$, tachypnea ( $>24 / \mathrm{min}$ ), white blood cell (WBC) count less than 4,000 cells $/ \mu$ lor greater than 12,000 cells $/ \mu$ l or the presence of more than 10\% immature neutrophils (band forms).

Pneumonia-derived sepsis was diagnosed when sepsis was accompanied by consolidations in chest X-ray, and no other site of infection. Positive blood and bronchioalveolar lavage (BAL) fluid bacteria cultures were obtained.

Intraabdominal sepsis was diagnosed when sepsis was secondary to abdominal surgery complications or severe necrotizing pancreatitis with no other site of infection.

Positive peripheral blood bacteria cultures and peritoneal fluid culture were obtained from all patients. We excluded patients under 18 years of age, cancer patients, HIV carriers and those receiving immunosuppressive treatment. The clinical severity of the patient's state was evaluated using the APACHE II scale.

Flow cytometry analysis. The blood samples for immunocytochemical analysis were collected from selected patients on average on the fifth day (between the fourth and the sixth day) of their stay at the ICU (Tables 1,2). One milliliter of peripheral blood was obtained from an arterial line, placed in EDTA and immediately sent to the laboratory. Immunocytochemical staining was performed using antibodies from BD Simultest (anti: CD45FITC/CD14PE, $\mathrm{IgG}_{1} /$ $/ \mathrm{IgG}_{2 \mathrm{a}}, \mathrm{CD} 3 \mathrm{FITC} / \mathrm{CD} 19 \mathrm{PE}, \mathrm{CD} 3 \mathrm{FITC} / \mathrm{CD} 4 \mathrm{PE}, \mathrm{CD} 3 \mathrm{FITC} /$ /CD8PE, CD16FITC/CD16 $\left.{ }^{+} \mathrm{CD} 56 \mathrm{PE}\right)$, as described previously [10]. This panel of antibodies has been internationally accepted for studies of leukocyte subpopulations. Briefly, $50 \mu \mathrm{l}$ of the blood was incubated with $10 \mu \mathrm{l}$ of labeled antibody for $30 \mathrm{~min}$ at room temperature. Subsequently, erythrocytes were lysed by the addition of lysing buffer (Beckton Dickinson). Afterwards, cells were washed twice with $2 \%$ calf serum in phosphate buffer saline, centrifuged and resuspended in PBS- $0.5 \%$ formaldehyde. Labeled cells were analyzed by flow cytometry using the FACS Calibur cytometer (Beckton Dickinson). 10,000 live leukocytes were collected from each sample. The obtained data was analyzed using CellQuest software (BD) and quadrant statistics. WBC was counted in the Burker chamber. Results were expressed as the total number of a cell type per $1 \mu \mathrm{l}\left(\mathrm{mm}^{3}\right)$ of blood. Normal values for populations and subpopulations of leukocytes in the peripheral blood of healthy persons were assayed and were similar to those previously published [11].

Statistical analysis. Results, expressed as median and interquartile ranges $\left(\mathrm{P}_{25}-\mathrm{P}_{75}\right.$ values), were analyzed using a commercial statistical application StatView 5.12. Most variables did not fulfill the normality hypothesis, so the Mann- 
Table 1. Characteristics of patients with pneumonia-derived sepsis

\begin{tabular}{|l|c|c|c|c|c|c|c|c|}
\hline No & $\begin{array}{c}\text { Sex } \\
(\text { Male/Female) }\end{array}$ & Age & Etiology & $\begin{array}{c}\text { Shock } \\
\text { (Yes/No) }\end{array}$ & Apache II & $\begin{array}{c}\text { Length of ICU } \\
\text { stay (days) }\end{array}$ & $\begin{array}{c}\text { Survival } \\
\text { (Yes/No) }\end{array}$ & $\begin{array}{c}\text { White Blood } \\
\text { Cell Count [ } \boldsymbol{\mu l}]\end{array}$ \\
\hline $\mathbf{1}$ & $\mathrm{F}$ & 50 & $\mathrm{G}^{-}$ & $\mathrm{Y}$ & 9 & 16 & $\mathrm{Y}$ & 11,950 \\
\hline $\mathbf{2}$ & $\mathrm{M}$ & 64 & $\mathrm{G}^{+}$ & $\mathrm{N}$ & 9 & 12 & $\mathrm{Y}$ & 13,325 \\
\hline $\mathbf{3}$ & $\mathrm{M}$ & 40 & $\mathrm{G}^{-}$ & $\mathrm{N}$ & 6 & 9 & $\mathrm{Y}$ & 10,450 \\
\hline $\mathbf{4}$ & $\mathrm{F}$ & 53 & $\mathrm{G}^{+}$ & $\mathrm{Y}$ & 15 & 30 & $\mathrm{~N}$ & 33,200 \\
\hline $\mathbf{5}$ & $\mathrm{F}$ & 42 & $\mathrm{G}^{+}$ & $\mathrm{N}$ & 9 & 49 & $\mathrm{~N}$ & 15,300 \\
\hline $\mathbf{6}$ & $\mathrm{M}$ & 60 & $\mathrm{G}^{+}$ & $\mathrm{N}$ & 6 & 17 & $\mathrm{~N}$ & 6,450 \\
\hline $\mathbf{7}$ & $\mathrm{M}$ & 30 & $\mathrm{G}^{+}$ & $\mathrm{N}$ & 10 & 6 & $\mathrm{~N}$ & 18,000 \\
\hline $\mathbf{8}$ & $\mathrm{F}$ & 40 & $\mathrm{G}^{+}$ & $\mathrm{Y}$ & 9 & 5 & $\mathrm{~N}$ & 1,950 \\
\hline \multicolumn{2}{l}{ Median or ratio } & 46 & $0.75 \mathrm{G}^{+}$ & $0.38 \mathrm{Y}$ & 9 & 14 & $0.37 \mathrm{Y}$ & 12,638 \\
\hline
\end{tabular}

ICU — Intensive Care Unit; APACHE II — Acute Physiology and Chronic Health Evaluation II — scores for the day of sample collection

Table 2. Characteristics of patients with intraabdominal sepsis

\begin{tabular}{|l|c|c|c|c|c|c|c|c|}
\hline No & $\begin{array}{c}\text { Sex } \\
(\text { Male/Female) }\end{array}$ & Age & Etiology & $\begin{array}{c}\text { Shock } \\
(\text { Yes/No) }\end{array}$ & Apache II & $\begin{array}{c}\text { Length of ICU } \\
\text { stay (days) }\end{array}$ & $\begin{array}{c}\text { Survival } \\
\text { (Yes/No) }\end{array}$ & $\begin{array}{c}\text { White Blood } \\
\text { Cell Count [ } \boldsymbol{\mu l} \text { ] }\end{array}$ \\
\hline $\mathbf{1}$ & $\mathrm{M}$ & 27 & $\mathrm{G}^{-}$ & $\mathrm{Y}$ & 11 & 85 & $\mathrm{~N}$ & 28,750 \\
\hline $\mathbf{2}$ & $\mathrm{M}$ & 50 & $\mathrm{G}^{-}$ & $\mathrm{N}$ & 9 & 8 & $\mathrm{~N}$ & 13,300 \\
\hline $\mathbf{3}$ & $\mathrm{F}$ & 63 & $\mathrm{G}^{-}$ & $\mathrm{Y}$ & 12 & 22 & $\mathrm{~N}$ & 25,020 \\
\hline $\mathbf{4}$ & $\mathrm{M}$ & 51 & $\mathrm{G}^{-}$ & $\mathrm{N}$ & 11 & 13 & $\mathrm{~N}$ & 37,450 \\
\hline $\mathbf{5}$ & $\mathrm{M}$ & 62 & $\mathrm{G}^{-}$ & $\mathrm{Y}$ & 15 & 52 & $\mathrm{~N}$ & 20,800 \\
\hline $\mathbf{6}$ & $\mathrm{F}$ & 40 & $\mathrm{G}^{+}$ & $\mathrm{Y}$ & 4 & 7 & $\mathrm{~N}$ & 15,100 \\
\hline $\mathbf{7}$ & $\mathrm{F}$ & 74 & $\mathrm{G}^{+}$ & $\mathrm{Y}$ & 20 & 43 & $\mathrm{~N}$ & 10,640 \\
\hline $\mathbf{8}$ & $\mathrm{M}$ & 48 & $\mathrm{G}^{-}$ & $\mathrm{N}$ & 9 & 5 & $\mathrm{~N}$ & 29,050 \\
\hline $\mathbf{9}$ & $\mathrm{M}$ & 56 & $\mathrm{G}^{-}$ & $\mathrm{N}$ & 9 & 21 & $\mathrm{~N}$ & 12,100 \\
\hline $\mathbf{1 0}$ & $\mathrm{M}$ & 40 & $\mathrm{G}^{-}$ & $\mathrm{Y}$ & 11 & 12 & $\mathrm{Y}$ & 14,200 \\
\hline $\mathbf{1 1}$ & $\mathrm{F}$ & 51 & $\mathrm{G}^{-}$ & $\mathrm{Y}$ & 13 & 5 & $\mathrm{Y}$ & 26,150 \\
\hline $\mathbf{1 2}$ & $\mathrm{M}$ & 83 & $\mathrm{G}^{-}$ & $\mathrm{Y}$ & 12 & 13 & $\mathrm{Y}$ & 25,000 \\
\hline $\mathbf{1 3}$ & $\mathrm{M}$ & 52 & $\mathrm{G}^{+}$ & $\mathrm{N}$ & 19 & 31 & $\mathrm{Y}$ & 14,600 \\
\hline $\mathbf{1 4}$ & $\mathrm{M}$ & 72 & $\mathrm{G}^{+}$ & $\mathrm{Y}$ & 13 & 13 & $\mathrm{Y}$ & 30,800 \\
\hline Median or ratio & 52 & $0.71 \mathrm{G}^{-}$ & $0.64 \mathrm{Y}$ & 11.5 & 13 & $0.36 \mathrm{Y}$ & 25,010 \\
\hline
\end{tabular}

ICU — Intensive Care Unit; APACHE II — Acute Physiology and Chronic Health Evaluation II — scores for the day of sample collection

-Whitney U-test for non-parametric data was used to analyze differences between the groups. Correlations between parameters were assessed using Spearman's rank correlation. Statistical significance was assumed when $\mathrm{p}<0.05$.

\section{Results}

\section{Patient population}

Out of 22 patients with diagnosed sepsis, eight patients fulfilled the criteria for oneumonia-derived sepsis (PDS) including double positive bacteria cultures from blood and bronchoalveolar lavage fluid (BALf), and 14 patients had intraabdominal sepsis (IAS) with double positive cultures from blood and peritoneal cavity. In the IAS group, five patients had acute necrotizing pancreatitis and the others had complications after major surgery. Clinical data from these two groups is summarized in Tables 1 and 2. In the PDS group, the Gram-positive species were isolated from six patients $(75 \%)$, while in the IAS group nine Gramnegative species were isolated (71\%). The ICU length of stay and the APACHE II scores and survival (0.38 for PDS and 0.36 for IAS) were comparable in both groups. Median age of healthy subjects (volunteers) was $31\left(\mathrm{P}_{25} 26-\mathrm{P}_{75} 55\right)$. 


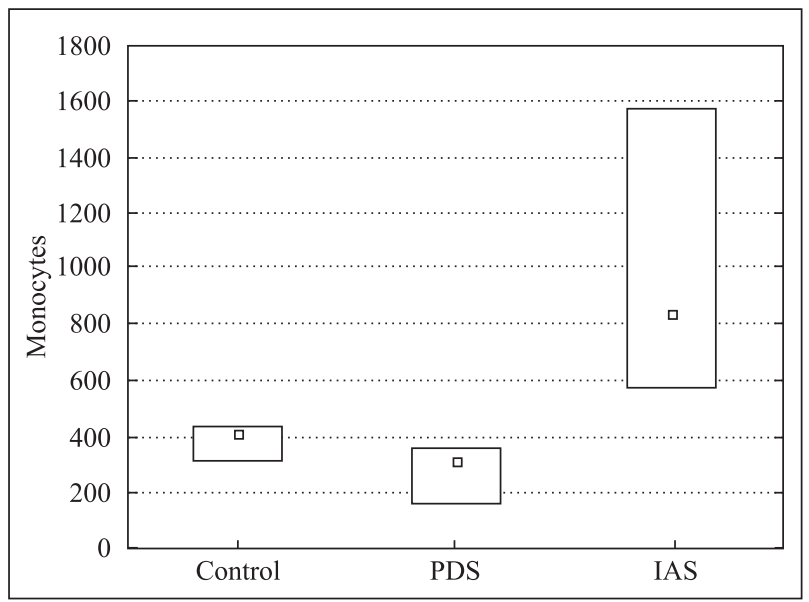

Figure 1. Absolute number of monocytes per $\mu$ l of peripheral blood in controls and septic patients

IAS — intraabdominal sepsis; PDS — pneumonia-derived sepsis. Results expressed as median and $\mathrm{P}_{25}-\mathrm{P}_{75}$ values

\section{Leukocyte subpopulation counts in intraabdominal sepsis and pneumonia-derived sepsis}

The septic patients enrolled in our study had a significantly higher value of absolute number of leukocytes compared to the healthy controls (4.10 ratio in IAS and 2.07 ratio in PDS). This was mainly due to the increased number of granulocytes (6.76 ratio in IAS and 3.42 in PDS). Intraabdominal sepsis was characterized by an increase in the absolute monocyte number (2.03 ratio), while in pneumonia-derived sepsis a slight decrease was observed (0.76 ratio), as presented in Figure 1. Lymphocyte subpopulations including $\mathrm{CD}^{+}, \mathrm{CD}^{+} / \mathrm{CD}^{+}, \mathrm{CD}^{+} / \mathrm{CD}^{+}, \mathrm{CD} 19^{+}$ and $\mathrm{NK}$ cells were diminished compared to controls in both types of sepsis. A marked drop of $\mathrm{CD}^{+} /$ $/ \mathrm{CD}^{+}$, NK and NKT cells was observed, with a tendency to a greater loss in pulmonary infections (Table 3, Figure 2).

\section{NK cells and CD8 T lymphocyte counts correlate independently of the infection type}

In order to analyze changes in the immune response during sepsis, we calculated correlations between lymphocyte subsets. During IAS, as well as PDS, total lymphocyte count per $\mu$ l correlated positively with the $\mathrm{CD}^{+} \mathrm{T}$ lymphocytes number (correlation coefficient $\mathrm{r}^{2}=0.95$ and $\mathrm{r}^{2}=0.99$, respectively). Correlations were also found between CD19+ B lymphocyte count and the total lymphocyte count (correlation coefficient $\mathrm{r}^{2}=0.85$ in IAS and $\mathrm{r}^{2}=0.97$ in PDS) and CD $4^{+}$ $\mathrm{T}$ lymphocyte count and $\mathrm{T}$ lymphocyte count $\left(r^{2}=0.90\right.$ in IAS and in PDS). Interestingly, the CD $8^{+}$ cytotoxic lymphocyte (CTL) population count better

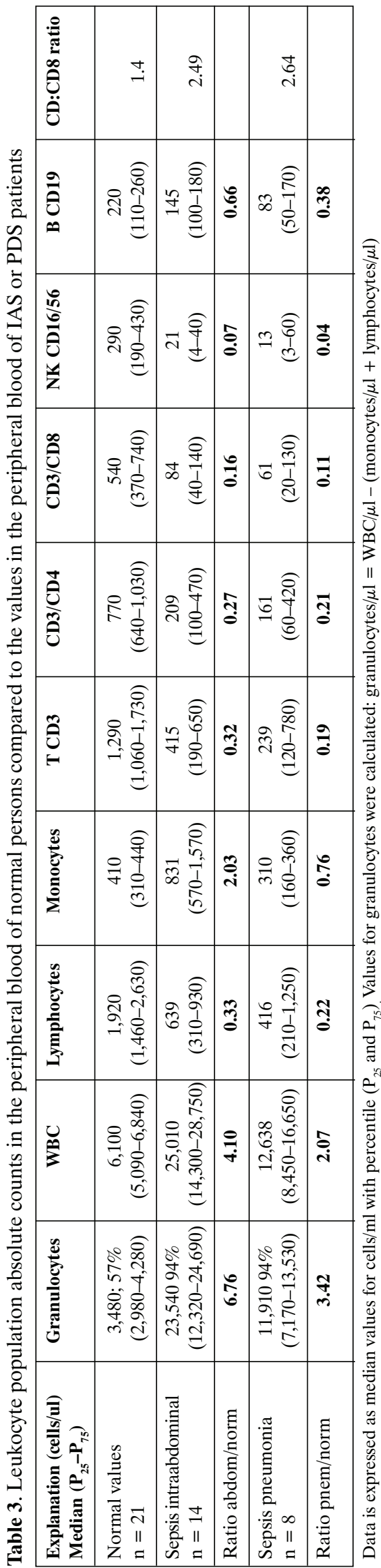




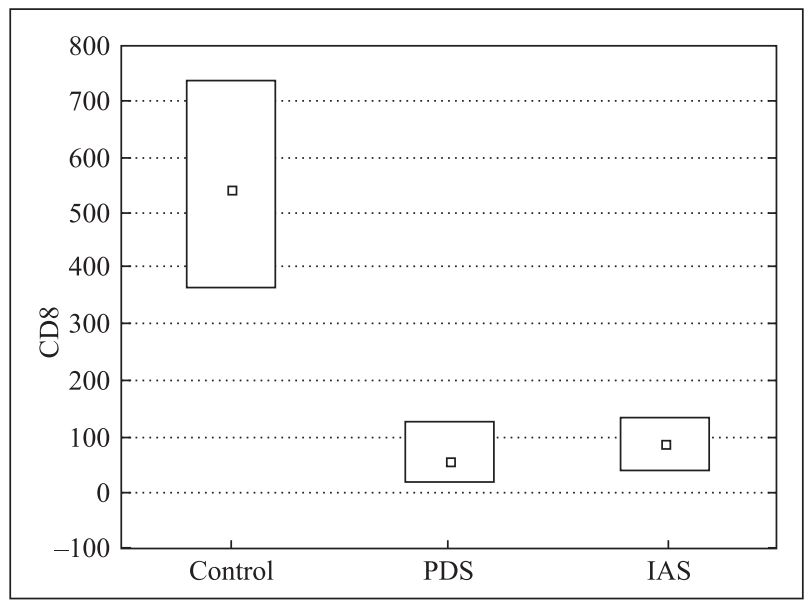

Figure 2. Absolute number of $\mathrm{CD} 3{ }^{+} \mathrm{CD} 8{ }^{+}$lymphocytes per $\mu l$ of peripheral blood in controls and septic patients

IAS — intraabdominal sepsis; PDS — pneumonia-derived sepsis. Results expressed as median and $\mathrm{P}_{25}-\mathrm{P}_{75}$ values

correlated with the total lymphocyte count in the PDS group $\left(\mathrm{r}^{2}=0.90\right)$ than in IAS $\left(\mathrm{r}^{2}=0.67\right)$, as did the count of NK cell population $\left(r^{2}=0.90\right.$ in PDS and $r^{2}=0.33$ in IAS). However, no differences were found in the count obtained for NK cells and CTL $\mathrm{CD}^{+} /$ $/ \mathrm{CD} 8^{+}$lymphocyte population, independently in both studied groups of patients. Significant correlations between lymphocyte subsets and APACHE II were found in neither IAS nor PDS patients.

\section{Discussion}

In this study, we identified differences of the circulating lymphocytes in sepsis derived from different sites of infection: lungs (PDS) and abdomen (IAS). The differences were analyzed during the later phase of sepsis when immune disturbances are well-pronounced. Although sepsis may have heterogeneous etiology, most studies on human sepsis have not focused on the site of origin of sepsis. Nevertheless, the site of origin may be important, as suggested by a few papers revealing differences in the immune response during $\mathrm{Gram}^{+}$and $\mathrm{Gram}^{-}$sepsis. The study by Holub et al. [4] showed that $\mathrm{Gram}^{+}$sepsis caused a higher decrease in $\mathrm{CD}^{+}, \mathrm{CD}^{+}$, NK cells and total T-lymphocytes than $\mathrm{Gram}^{-}$sepsis. The pattern of immune recovery in $\mathrm{Gram}^{+}$sepsis was different and slower than in Gram- infections [4]. Gram positive sepsis is often related to higher mortality than Gram negative sepsis [12] and PDS is mostly of $\mathrm{G}^{+}$etiology, as in our observations. Another study comparing ventilator associated pneumonia (VAP) with other infections showed stronger depression of CD $4+$ lymphocytes and lower release of TNF by in vitro LPS stimulated monocytes of VAP patients [13].
Our observations revealed differences in the circulating leukocyte populations between sepsis derived from different sites of infection i.e. the lungs (PDS) and the abdomen (IAS). Both analyzed types of sepsis were characterized by an increase in the granulocyte absolute count, but there was a difference between them: a higher granulocyte number was present in IAS. An excess production and release of neutrophils to peripheral blood is a known phenomenon in peritonitis [14, 15], although the migration of polymorphonuclear neutrophils to lungs during peritonitis in nonsurviving patients has also been reported [16]. One of the main functions of this population of cells is to trap the circulating bacteria within the neutrophil DNA-protein net (NET, neutrophil extracellular trap) released from the dying cells [17]. Interestingly, we observed a marked difference in monocyte population counts. While in PDS the monocyte count decreased, in IAS an increase was observed. The analysis of peripheral blood leukocytes reflects either their turn-over or their translocation from circulation to the tissues and reverse. In a recent paper, Gogos et al. [8] showed similar rates of monocyte apoptosis in sepsis derived from peritonitis, CAP and VAP. Given this, our results suggest a translocation of monocyte population to the inflamed lungs in PDS which is consistent with the experimental data. Murine models of local lung inflammation have revealed a sequestration of bone marrow released monocytes, but also an observation that transfer of monocytes from pneumonic animals to healthy animals led to the accumulation of the activated monocytes in the healthy lungs $[18,19]$. As mentioned above, IAS was characterized by an increase in the total number of circulating monocytes which is typical in sepsis derived from peritonitis [20]. This rise in the circulating monocyte number can be explained by their release from bone marrow as well as the clearance from peritoneal cavity [21].

Our study did not reveal significant differences in the total count of lymphocytes subpopulations in IAS and PDS. However, this may be a result of the small sample size, partially mitigated by the strong differentiation of the two compared groups. The analyzed lymphocyte counts were lower compared to healthy controls. A tendency to a more pronounced loss of circulating $\mathrm{CD}^{+}$cytotoxic T cells (CTL) and NK cells could be seen in the pulmonary sepsis. While the decrease of $\mathrm{CD}^{+} \mathrm{CTL}$ is consistent with previous reports [8, 22], our observations regarding the population of NK cells are surprisingly not. Several papers have reported an increased number of NK cells in sepsis [23, 24].

In order to further investigate elements of cellular immune response in sepsis, we calculated correlations between lymphocyte subsets. NK cells and $\mathrm{CD} 8^{+}$cyto- 
toxic lymphocytes counts were correlated with the total lymphocyte count only in the PDS patients. This might suggest a different role of these cells during abdominal and lung infections. $\mathrm{CD} 8^{+}$lymphocytes are known to play a key role in peritoneal immune mechanisms and the CD4:CD8 ratio is inverted in the peritoneal fluid compared to the peripheral blood [5]. During abdominal infections, these cells may be recruited from the peripheral blood into the local compartment. The same might occur with NK cells which are known to be attracted by factors produced by mesothelial cells of the peritoneal cavity, such as IL-15 which is an important ligand for both NK cells and CD8 ${ }^{+}$lymphocytes [25].

Additionally, we found a similar relationship between NK cells and CD8 ${ }^{+}$lymphocytes in both types of sepsis. This finding supports a hypothesis based on a murine sepsis model that $\mathrm{NK}$ and $\mathrm{CD} 8^{+}$lymphocytes play an important role in extracellular bacterial infections [26]. NK cells are known to be major INF $\gamma$ producers during bacterial sepsis. The INF $\gamma$ cytokine is produced by NK cells in response to IL-12 and activates macrophages (potentiate phagocytosis, oxidative burst, production of TNF $\alpha$ and IL-12) and Th cells [27]. In the animal CLP-model, it has been shown that NK cells migrate into the peritoneal cavity where they appear to facilitate the activation of peritoneal macrophages [28]. Despite such effects in an infection, the peripheral blood depletion of NK cells improved the outcome of the septic animals. This effect was even stronger when the mice were devoid of NK cells and $\mathrm{CD}^{+}$lymphocytes at the same time [26]. Although these cells were not considered as important players in extracellular bacterial infections, they have additive and synergistic effects on each other in sepsis. Our results suggest the existence of this phenomenon in human sepsis. Gimarellos-Bourboulis et al. [23] suggested that a high NK cell count was a positive prognostic factor in G-sepsis, and Monserrat et al. [22], observed significantly lower $\mathrm{CD} 3{ }^{+} \mathrm{CD} 8^{+} \mathrm{T}$ cell counts in survivors compared to nonsurvivors, but we did not find any correlation between the clinical state of patients as evaluated by the APACHE II scale, NK cells or $\mathrm{CD} 8^{+}$lymphocytes. A correlation between NK cells and $\mathrm{CD} 3 / \mathrm{CD}^{+}$absolute counts may suggest a common regulatory mechanism for these cell types. As stated before, INF $\gamma$ produced by NK cells may favor $\mathrm{CD} 3 / \mathrm{CD}^{+}$lymphocytes as IL-12 does. Another independent mechanism responsible for this correlation may involve receptors CD94/NKG2 expressed both by NK cells as well as a subset of CD3/ $/ \mathrm{CD}^{+} \mathrm{T}$-cells active in infections. NKG2A functions as an inhibitory receptor when forming heterodimers with an invariant chain, CD94 [29, 31]. Several in vivo models have shown that the acquisition of CD94/ /NKG2A expression by $\mathrm{CD} 8^{+} \mathrm{T}$ cells could play a role during infection by pathogens. As a consequence of $\mathrm{CD}^{+} \mathrm{T}$ cell activation by an antigen, these cells start expressing CD94/NKG2A. This has been observed in mice infected with a variety of pathogens, including Listeria monocytogenes [31-33]. The expression of CD94/ /NKG2A is acquired early during the infection and persists after the clearance of the pathogen. In some of these studies, it was shown that the expression of CD94/ /NKG2A by the CD8 ${ }^{+} \mathrm{T}$ cells did not inhibit cytotoxic function of these cells $[31,33]$. These receptors are specific for the nonclassical class I molecule HLA-E in humans [33-35] and Qa-1b in mice [37]. The other observed function of the CD94/NGK2 receptor is to protect the NK and CD8 T cells from apoptosis, thereby perhaps aiding in the generation of memory cells [38].

In conclusion, we have observed that some components of the immune response during sepsis may depend on the site of infection. Intra-abdominal sepsis was characterized by a high monocyte count, while pneumonia-derived sepsis led to a decrease in the number of circulating monocytes. Both sepsis types led to the loss of peripheral blood lymphocytes, including CD3/CD ${ }^{+}$CTL and NK cells. We also found similar behavior by the NK cells and $\mathrm{CD} 3 / \mathrm{CD} 8^{+} \mathrm{CTL}$ in the course of bacterial sepsis. However, additional studies on both the $\mathrm{NK}$ cells and the $\mathrm{CD} 3 / \mathrm{CD} 8^{+}$cells in the pathogenesis of human sepsis are needed.

\section{Abbreviations}

APACHE - Acute Physiology and Chronic Health Evaluation; CTL - cytotoxic lymphocyte; IAS - intraabdominal sepsis; ICU — intensive care unit; NK cells Natural Killer cells; PDS — pneumonia-derived sepsis.

\section{Funding}

This study was supported by the European Union Structural Funds, 'Innovative methods of stem cells applications in medicine', Innovative Economy Operational Program, grant no. POIG 01.02-00-109/09 and grant no. 501-1-1-01-32/08 Postgraduate Medical School Center.

\section{Acknowledgements}

T.S. would like to thank Chris Kozak for his helpful comments.

\section{References}

1. Angus DC, Linde-Zwirble WT. Epidemiology of severe sepsis in the United States: analysis of incidence, outcome, and associated costs of care. Crit Care Med. 2001;29:1303-1310.

2. Levy MM, Dellinger PR, Townsend SR et al. The Surviving Sepsis Campaign: results of an international guideline-based performance improvement program targeting severe sepsis. Intensive Care Med. 2010;36:222-231. 
3. Hotchkiss RS, Karl IE. The patophysiology and treatment of sepsis. N Engl J Med. 2003;348:138-150.

4. Holub M, Kluckov $\beta$ Z, Helcl M, Príhodov J, Rokyta R, Beran O. Lymphocyte subset numbers depend on the bacterial origin of sepsis. Clin Microbiol Infect. 2003;9:202-211.

5. Glik A, Douvdevani A. T lymphocytes: the 'cellular' arm of aquired immunity in the peritoneum. Perintoneal Dialysis International. 2006;26:438-448.

6. Domagała-Kulawik J. Effects of cigarette smoke on the lung and systemic immunity.J Physiol Pharmacol. 2008;59(Suppl 6):19-34.

7. Lattere PF, Garber G, Levy H et al. Severe community-acquired pneumonia as a causa of severe sepsis: Data from the PROWESS study. Crit Care Med. 2005;33:952-961.

8. Gogos C, Kotsaki A, Pelekanou A et al. Early alterations of the innate and adaptive immune statuses in sepsis according to the type of underlying infection. Crit Care. 2010;14:R96, s1-12.

9. Bone RC, Balk RA, Cerra FB et al. Definitions for sepsis and organ failure and guidelines for the use of innovative therapies in sepsis. The ACCP/SCCM Consensus Conference Committee. American College of Chest Physicians/Society of Critical Care Medicine. Chest. 1992;101:1644-1655.

10. Domagała-Kulawik J, Hoser G, Droszcz P, Kawiak J, Droszcz W, Chazan R. T-cell subtypes In Bronchoalveolar Lavage fluid and In peripheral blond from patients with primary lung cancer. Diagn Cytopathol. 2001;25:208-213.

11. Hulstaert F, Hannet I, Deneys V et al. Age-related changes of human blood lymphocyte subpopulations. Clin Immunol Immunopathol. 1994;70:152-158.

12. Gao H, Evans TW, Finney SJ. Bench-to-bedside review: sepsis, severe sepsis and septic shock - does the nature of the infecting organism matter? Crit Care. 2008;12:213 (doi:10.1186/cc6862).

13. Pelekanou A, Tsangaris I, Kotsaki A et.al. Decrease of CD4lymphocytes and apoptosis of CD14-monocytes are characteristic alterations in sepsis caused by ventilatior-associated pneumonia: results from an observational study. Crit Care. 2009;13:R172 (doi:10.1186/cc8148).

14. Barthlen W, Zantl N, Pfeffer K, Heidecke CD, Holzmann B, Stadler J. Impact of experimental peritonitis on bone marrow cell function. Surgery. 1999;126:41-47.

15. Nathan C. Neutrophils and immunity: challenges and opportunities. Nat Rev Immunol. 2006;6:173-182.

16. van Till JW, van Veen SQ, den Broeder V et al. Compartmental apoptosis and neutrophil accumulation in severe peritonitis. J Surg Res. 2010;64:321-328.

17. Fuchs TA, Abed U, Goosmann C et al. Novel cell death program leads to neutrophil extracellular traps. J Cell Biol. 2007;176:231-241.

18. Goto Y, Hogg JC, Whalen B, Shih CH, Ishii H, van Eeden S. Monocyte Recruitment into the lungs In Pneumococcal Pneumonia. Am J Respir Cell Mol Biol. 2004;30:620-626.

19. Maus UA, Janzen S, Wall $\mathrm{G}$ et al. Resident alveolar macrophages are replaced by recruited monocytes in response to endotoxin-induced lung inflammation. Am J Respir Cell Mol Biol. 2006;35:227-235.

20. Schinkel C, Sendtner R, Zimmer S, Faist E. Functional analysis of monocyte subsets in surgical sepsis. J Trauma. 1998;44:743-748.

21. Bellingan GJ, Xu P, Cooksley $\mathrm{H}$ et al. Adhesion moleculedependent mechanisms regulate the rate of macrophage clearance during the resolution of peritoneal inflammation. J Exp Med. 2002;196:1515-1521.
22. Monserrat J, de Pablo R, Reyes E et al. Clinical relevance of the severe abnormalities of the T cell compartment in septic shock patients. Crit Care. 2009;13:R26 (doi:10.1186/cc7731).

23. Giamarellos-Bourboulis EJ, Tsaganos T, Spyridaki E et al. Early changes of CD4-positive lymphocytes and NK cells in patients with severe Gram-negative sepsis. Crit Care. 2006;10:R166 (doi:10.1186/cc5111).

24. Hotchkiss RS, Osmon SB, Chang KC, Wagner TH, Coopersmith CM, Karl IE. Accelerated lymphocyte death in sepsis occurs by both the death receptor and mitochondrial pathways. J Immunol. 2005;174:5110-5118.

25. Alpdogan O, van den Brink MR. IL-7 and IL-15: therapeutic cytokines for immunodeficiency. Trends Immunol. 2005;26:56-64.

26. Sherwood ER, Enoh VT, Murphey ED, Lin CY. Mice depleted of $\mathrm{CD}^{+} \mathrm{T}$ and NK cells are resistant to injury caused by cecal ligation and puncture. Lab Invest. 2004;84:1655-1665.

27. Godshall CJ, Scott MJ, Burch PT, Peyton JC, Cheadle WG. Natural killer cells participate in bacterial clearance during septic peritonitis through interactions with macrophages. Shock. 2003;19:144-149.

28. Etogo AO, Nunez J, Lin CY, Toliver-Kinsky TE, Sherwood ER. NK but not CD1-restricted NKT cells facilitate systemic inflammation during polymicrobial intra-abdominal sepsis. J Immunol. 2008;180:6334-6345.

29. Brooks AG, Posch PE, Scorzelli CJ, Borrego F, Coligan JE. NKG2A complexed with CD94 defines a novel inhibitory natural killer cell receptor. J Exp Med. 1997;185:795-800.

30. Carretero M, Cantoni C, Bellon T et al. The CD94 and NKG2-A C-type lectins covalently assemble to form a natural killer cell inhibitory receptor for HLA class I molecules. Eur J Immunol. 1997;27:563-567.

31. McMahon CW, Zajac AJ, Jamieson AM et al. Viral and bacterial infections induce expression of multiple NK cell receptors in responding CD8(+) T cells.J Immunol. 2002;169:1444-1452.

32. Gunturi A, Berg RE, Forman J. Preferential survival of CD8 $\mathrm{T}$ and NK cells expressing high levels of CD94. J Immunol. 2003;170:737-1745.

33. Miller JD, Peters M, Oran AE et al. CD94/NKG2 expression does not inhibit cytotoxic function of lymphocytic choriomeningitis virus-specific CD8+ T cells. J Immunol. 2002;169:693-701 .

34. Borrego F, Ulbrecht M, Weiss EH, Coligan JE, Brooks AG. Recognition of human histocompatibility leukocyte antigen (HLA)-E complexed with HLA class I signal sequence-derived peptides by CD94/NKG2 confers protection from natural killer cell-mediated lysis. J Exp Med. 1998;187:813-818.

35. Petrie EJ, Clements CS, Lin J et al. CD94-NKG2A recognition of human leukocyte antigen (HLA)-E bound to an HLA class I leader sequence. J Exp Med. 2008;205:725-735.

36. Lee $\mathrm{N}$, Llano $\mathrm{M}$, Carretero $\mathrm{M}$ et al. HLA-E is a major ligand for the natural killer inhibitory receptor CD94/NKG2A.Proc Natl Acad. Sci. 1998;95:5199-5204.

37. Vance RE, Kraft JR, Altman JD, Jensen PE, Raulet DH. Mouse CD94/NKG2A is a natural killer cell receptor for the nonclassical major histocompatibility complex (MHC) class I molecule Qa-1(b). J Exp Med. 1998;188:1841-1848.

38. Gunturi A, Berg RE, Forman J. The role of CD94/HGK2 in innate and adaptive immunity. Immunol Res. 2004;30:29-34. 